\title{
HUBUNGAN DUKUNGAN KELUARGA DENGAN PERILAKU IBU DALAM MELAKSANAKAN PROGRAM KELUARGA SADAR GIZI (KADARZI) PADA KASUS BALITA DENGAN KURANG GIZI
}

\author{
(The Relationship between Family Support and Mother's Behavior in Implementing \\ Nutritional Family Programs (KADARZI) in the Case of Children with Malnutrition)
}

\author{
Nurul Fitrianil Jannah, Elida Ulfiana dan Sylvia Dwi Wahyuni
}

Fakultas Keperawatan, Universitas Airlangga, Surabaya, Indonesia

\section{RIWAYAT ARTIKEL}

Diterima: 20 Juli 2020

Disetujui: 28 September 2020

\section{KONTAK PENULIS}

Nurul Fitrianil Jannah nurulfitrianiljannah@gmail.com Fakultas Keperawatan, Universitas Airlangga

\begin{abstract}
ABSTRAK
Pendahuluan: Keluarga dengan balita kurang gizi merupakan salah satu sasaran program Kementrian Kesehatan yaitu Keluarga Sadar Gizi (KADARZI). Masih banyaknya masalah gizi pada balita dan persentase KADARZI yang belum mencapai target nasional 80\% menunjukkan bahwa asuhan gizi di tingkat keluarga belum memadai. Salah satu penghambat KADARZI adalah ibu tidak mendapatkan dukungan dari keluarga. Tujuan penelitian ini adalah untuk mengetahui hubungan dukungan keluarga dengan perilaku ibu dalam melaksanakan program keluarga sadar gizi (KADARZI) pada kasus balita dengan kurang gizi.
\end{abstract}

Metode: Penelitian ini menggunakan rancangan penelitian korelasional dengan pendekatan cross sectional. Populasi dalam penelitian ini adalah ibu yang memiliki balita kurang gizi berusia 12-59 bulan di Surabaya. Sampel penelitian ini berjumlah 107 responden yang diperolah menggunakan teknik purposive sampling. Variabel independen adalah dukungan keluarga. Variabel dependen adalah perilaku ibu balita yang kurang gizi dalam melaksanakan KADARZI. Instrumen yang digunakan adalah kuesioner. Data penelitian dianalisis menggunakan SPSS dengan uji Spearman Rho dengan tingkat signifikansi $\mathrm{p}=0,05$.

Hasil: Hasil penelitian menunjukkan hubungan dukungan keluarga dengan perilaku KADARZI $(p=0,000)$ dengan arah korelasi yang bernilai positif.

Kesimpulan: Terdapat dukungan keluarga berhubungan dengan perilaku ibu balita dalam melaksanakan KADARZI. Semakin baik dukungan keluarga maka semakin baik pula perilaku ibu dalam melaskanakan KADARZI. Perawat Komunitas dapat memberikan intervensi berupa penyuluhan tentang pentingnya KADARZI agar ibu balita dan keluarga termotivasi untuk melaksanakan kelima indikator KADARZI.

\section{Kata Kunci}

balita; dukungan keluarga; KADARZI; malnutrisi., perilaku ibu

\begin{abstract}
Introduction: Families with toddler's underweight was one of the targets of the Ministry of Health program called Keluarga Sadar Gizi (KADARZI). Until now, the number of nutrition problems in toddlers and the percentage of KADARZI have not reached the national target, which is $80 \%$. This indicates that nutrition at the family level was inadequate. One obstacle to implement KADARZI was mothers that did not get support from the family. The aim of this study was to determine the relationship between family support and mother's behavior in implementing nutritional family programs (KADARZI) in the case of children with malnutrition.

Method: The design of this study was correlational study with a cross sectional approach. The population in this study were mothers who had underweight toddler aged 12-59 months in Surabaya. The sample of this study consisted of 107 respondents who were obtained using a purposive sampling technique. The independent variable was family support. The dependent variable was the behavior of mothers with underweight toddlers
\end{abstract}


in implementing KADARZI. The instrument used was a questionnaire. Data were analyzed using Spearman Rho test with a significance level of $p=0.05$.

Result: The results showed there was correlation between family support and behaviour of implementing KADARZI $(p=0,000)$ with a positive correlation.

Conclusion: Family support was affecting the behaviour of mothers with toddler's weight under red line in implementing KADARZI. The better the family support, the better the mother's behavior in implementing KADARZI. Community Nurses can provide counseling about the importance of KADARZI so that mothers of toddlers and families are motivated to implement the five KADARZI indicators.

\section{Keywords}

children; family support; KADARZI; malnutrition; mother's behavior

Kutip sebagai:
Jannah, N, F., Ulfiana, E., \& Wahyuni, S. D. (2020). Hubungan Dukungan Keluarga dengan Perilaku Ibu dalam Melaksanakan Program Keluarga Sadar Gizi (KADARZI) pada Kasus Balita dengan Kurang Gizi. Indonesian J. of Community Health Nurs. J., 5(2), 88-95. Doi: 10.20473/ijchn.v5i2.20847

\section{PENDAHULUAN}

Masalah gizi merupakan masalah kesehatan kompleks pada masyarakat seluruh dunia, terutama pada masyarakat di negara berkembang seperti Indonesia. Masalah gizi yang terjadi pada anak balita di Indonesia adalah berat badan balita di Bawah Garis Merah (BGM) atau kurang gizi. Balita kurang gizi apabila tidak ditangani dengan baik maka akan bertambah parah dan dapat menjadi gizi buruk (Kementrian Kesehatan RI, 2017). Keluarga dengan balita kurang gizi merupakan salah satu sasaran program Kementrian Kesehatan yaitu Keluarga Sadar Gizi (KADARZI). KADARZI merupakan suatu keluarga yang mampu mengenal, mencegah, dan mengatasi masalah gizi setiap anggotanya. Keluarga dikatakan KADARZI apabila keluarga tersebut berperilaku gizi yang baik yaitu dengan memenuhi lima indikator KADARZI. Indikator tersebut adalah menimbang berat badan secara teratur, memberikan Air Susu Ibu (ASI) saja kepada bayi sejak lahir sampai umur 6 bulan (ASI eksklusif), makan beraneka ragam, menggunakan garam beryodium dan minum suplemen gizi (kapsul Vitamin A atau Tablet Tambah Darah (TTD)) sesuai anjuran.

Pemerintah Indonesia menetapkan target nasional dari pelaksanaan KADARZI adalah $80 \%$ keluarga harus menerapkan perilaku KADARZI. Perilaku KADARZI di Jawa Timur pada tahun 2018 yang mencapai target nasional adalah menimbang berat badan secara rutin di posyandu dan penggunaan garam beryodium. Jumlah balita yang ditimbang di Posyandu sebesar 80,8\%. Cakupan pemberian ASI eksklusif pada bayi sebesar $76,98 \%$, angka ini belum mencapai target nasional yaitu $80 \%$. Keluarga yang menggunakan garam beryodium sebesar 93,9\%, angka ini sudah diatas target yaitu sebesar 80\%. Anak balita yang mendapatkan kapsul vitamin A sebesar 79,20\%. Perilaku makan sayur dan buah setiap hari hanya $59,2 \%$, nilai ini masih jauh dari $80 \%$ target nasional (Kementrian Kesehatan RI, 2018). Hasil studi pendahuluan yang dilakukan pada tanggal 9 April 2019 pada ibu balita kurang gizi di wilayah kerja puskesmas di Surabaya menunjukkan bahwa hanya 4 dari 10 ibu yang melaksanakan seluruh indikator KADARZI. Persentase balita kurang gizi di Jawa Timur mencapai 13,40 \% (Kementrian Kesehatan RI, 2018). Sebanyak 63 puskesmas yang ada di Surabaya, puskesmas Simomulyo tercacat memiliki balita BGM terbanyak. Jumlah balita kurang gizi di wilayah kerja puskesmas Simomulyo sebanyak 167 balita $(3,17 \%)$ dengan rincian anak balita laki-laki 86 orang $(3,23 \%)$ dan anak balita perempuan 81 orang (3,11\%) (Dinas Kesehatan Surabaya, 2018).

Dukungan yang diberikan oleh keluarga mempunyai peranan penting dalam pengambilan keputusan akhir tindakan ibu, karena segala sesuatu yang akan dilakukan ibu harus mendapat persetujuan dari keluarga. Salah satu penghambat KADARZI adalah ibu tidak mendapatkan dukungan dari keluarga, hal ini disebabkan karena keluarga mereka tidak mengetahui adanya program KADARZI. Dukungan dari keluarga sangat diperlukan seorang ibu untuk berperilaku KADARZI. Dampak dari kurangnya kesadaran dalam menerapkan perilaku KADARZI adalah akan meningkatkan risiko kejadian gizi buruk pada balita. Balita yang telah mengalami berat badan yang rendah berisiko mengalami gizi buruk jika tidak segera tertangani dengan baik, salah satu upaya untuk mengatasi masalah ini adalah dengan menerapkan perilaku KADARZI.

Hasil penelitian sebelumnya menjelaskan terdapat hubungan antara dukungan suami, peran dan fungsi kader, pengetahuan dan budaya keluarga pada pelaksanaan KADARZI (Saputri, 2016). Hasil penelitian lain yang dilakukan oleh Oktalina (2015), bahwa dukungan keluarga berpengaruh sebagai faktor penguat motivasi ibu untuk berperilaku memberikan ASI eksklusif yang merupakan salah satu indikator KADARZI. Dukungan keluarga juga berpengaruh pada perilaku ibu balita dalam menimbang anaknya ke posyandu. Ibu balita yang mendapat dukungan dari keluarga dengan baik 


\section{N. F. JANNAH ET AL.}

berpeluang berperilaku baik dalam menimbang anaknya ke posyandu (Djamil, 2017).

Penelitian sebelumnya telah menjelaskan hubungan dari faktor predisposisi (pengetahuan, sikap, kepercayaan, dan budaya keluarga), faktor pendukung (pelayanan kesehatan), dan faktor pendorong (karakteristik keluarga, dukungan suami, sosial ekonomi, dan peran kader) dengan perilaku KADARZI. Dukungan keluarga merupakan salah satu faktor pendorong seseorang untuk berperilaku, dalam penelitian sebelumnya belum dapat dijelaskan. Berdasarkan uraian diatas, peneliti tertarik untuk meneliti terkait hubungan dukungan keluarga dengan perilaku ibu dalam melaksanakan program Keluarga Sadar Gizi (KADARZI) pada kasus balita dengan kurang gizi.

\section{METODE}

Desain penelitian yang digunakan dalam penelitian ini adalah deskriptif korelatif dengan pendekatan cross sectional $\neg$. Populasi dalam penelitian ini adalah ibu balita kurang gizi di Puskesmas Surabaya yang berjumlah 148 orang. Sampel yang digunakan dalam penelitian yaitu ibu balita kurang gizi yang memenuhi kriteria inklusi dan eksklusi yaitu berjumlah 107 responden yang diperoleh menggunakan teknik purposive sampling. Kriteria inklusi pada penelitian ini antara lain: ibu harus tinggal satu rumah dengan balita kurang gizi; ibu dapat membaca dan menulis; ibu mengasuh balita secara mandiri. Kriteria eksklusi dalam penelitian ini adalah ibu yang memiliki balita kurang gizi dengan penyakit infeksi. Terdapat 2 jenis variabel yang diteliti dalam penelitian ini, yaitu variabel independen meliputi dukungan keluarga dan variabel dependen meliputi perilaku ibu balita kurang gizi dalam melaksanakan KADARZI. Instrumen yang digunakan adalah kuesioner data demografi ibu dan balita, kuesioner dukungan keluarga yang terdiri dari 20 pertanyaan, dan kuesioner perilaku KADARZI yang terdiri dari 5 pertanyaan. Kuesioner dukungan keluarga telah diuji validitas menggunakan program statistika SPSS dengan $r$ hitung antara $0,472-0,875(\mathrm{r}$ tabel $=0,3961)$ dan hasil uji reliabilitas dengan alpha cronbach 0,944 . Hasil uji validitas perilaku KADARZI didapatkan $r$ hitung antara 0,478-0,870 ( $\mathrm{r}$ tabel $=0,3961)$, serta telah diuji reliabilitasnya dengan hasil 0,810. Peneliti menganalisis data menggunakan SPSS dengan uji Spearman Rho dengan tingkat kemaknaan $<0,05$. Penelitian ini telah dinyatakan laik etik oleh Komite Etik Penelitian Kesehatan Fakultas Keperawatan Universitas Airlangga.

\section{HASIL}

Tabel 1 menunjukkan bahwa sebagian besar responden berusia 26-35 tahun yaitu sebanyak 71 responden $(66,4 \%)$. Pendidikan terakhir sebagian dari keseluruhan responden berpendidikan terakhir SMP yaitu sebanyak 50 responden (46,7\%). Hampir seluruh responden adalah ibu rumah tangga yaitu sebanyak 98 responden (91,6\%). Penghasilan keluarga dalam 1 bulan pada hampir seluruh responden berpenghasilan $\leq R P$. 3.800 .000 yaitu
Tabel 1. Data Demografi Responden ( $n=107)$

\begin{tabular}{lcc}
\hline \multicolumn{1}{c}{ Variabel } & n & \% \\
\hline Usia Ibu & 17 & 15,9 \\
17-25 tahun & 71 & 66,4 \\
26-35 tahun & 19 & 17,7 \\
36-45 tahun & & \\
Pendidikan Terakhir & 4 & 3,7 \\
$\quad$ SD & 50 & 46,7 \\
SMP & 49 & 45,8 \\
SMA & 4 & 3,7 \\
$\quad$ Perguruan Tinggi & & \\
Pekerjaan & 98 & 91,6 \\
Ibu rumah tangga & 2 & 1,9 \\
Swasta & 5 & 4,7 \\
Wiraswasta & 2 & 1,9 \\
Buruh & & \\
Penghasilan Keluarga & 97 & 90,7 \\
$\quad$ Rp. 3.800.000/bulan & 10 & 9,3 \\
$\quad$ Rp. 3.800.00/bulan & & \\
Alamat rumah & 37 & 34,6 \\
Kelurahan Sukomanunggal & 70 & 65,4 \\
Kelurahan Simomulyo & & \\
Usia Balita & 35 & 32,7 \\
12-36 bulan & 72 & 67,3 \\
37-59 bulan & &
\end{tabular}

sebanyak 97 responden (90,7\%) . Sebagian besar responden berasal dari kelurahan Simomulyo yaitu sebanyak 70 responden $(65,4 \%)$. Usia balita terdapat sebagian besar berusia 37-59 bulan yaitu sebanyak 72 balita $(67,3 \%)$. Jenis kelamin balita hampir sama antara laki-laki dan perempuan yaitu 54 anak (50,5\%) dan 53 anak (49,5\%).

Dukungan keluarga yang dirasakan oleh ibu balita kurang gizi berdasarkan tabel 2 diketahui sebagian besar memiliki dukungan keluarga yang cukup yaitu sebanyak 48 responden $(44,9 \%)$. Hanya 18 responden $(16,8 \%)$ yang memiliki dukungan keluarga yang baik.

Berdasarkan tabel 2 dijelaskan bahwa dukngan emosional pada responden sebagian besar cukup yaitu sebanyak 65 responden $(60,7 \%)$. Dukungan penghargaan responden sebagian besar cukup yaitu sebanyak 68 responden (63,6\%). Dukungan instrumental dan informatif yang dirasakan responden sebagian besar adalah cukup yaitu sebanyak 64 responden $(59,8 \%)$ dan 63 responden (58,9\%). Dukungan instrumental merupakan dukungan yang paling banyak responden menerima dukungan yang baik yaitu sebanyak 27 responden $(25,2 \%)$.

Berdasarkan tabel 2 menunjukkan bahwa sebagian besar balita melakukan penimbangan berat badan secara teratur sebanyak 95 balita $(88,8 \%)$. Balita yang menerima ASI ekslusif yaitu sebanyak 72 balita (67,3\%). Mayoritas balita belum mengkonsumsi makanan beragam yaitu sebanyak 79 balita $(73,8 \%)$. 106 responden $(99,1 \%)$ telah menunggunakan garam beryodium, hanya 1 responden $(0,9 \%)$ yang belum menggunakan garam beryodium. Hampir seluruh balita telah mendapatkan suplemen vitamin A yaitu sebanyak 103 balita (96,3\%). Perilaku KADARZI diukur minimal dengan 5 indikator yang menggambarkan perilaku sadar gizi. 
Tabel 2. Distribusi Variabel

\begin{tabular}{|c|c|c|c|c|c|c|c|c|}
\hline & \multicolumn{2}{|c|}{ Kurang } & \multicolumn{2}{|c|}{ Cukup } & \multicolumn{2}{|c|}{ Baik } & \multicolumn{2}{|c|}{ Total } \\
\hline & $\mathbf{n}$ & $\%$ & $\mathrm{n}$ & $\%$ & $\mathbf{n}$ & $\%$ & n & $\%$ \\
\hline Dukungan keluarga & 41 & 38,8 & 48 & 44,9 & 18 & 16,8 & 107 & 100 \\
\hline Dukungan Emosional & 28 & 26,2 & 65 & 60,7 & 14 & 13,1 & 107 & 100 \\
\hline Dukungan Penghargaan & 22 & 20,6 & 68 & 63,6 & 17 & 15,9 & 107 & 100 \\
\hline Dukungan Instrumental & 16 & 15 & 64 & 59,8 & 27 & 25,2 & 107 & 100 \\
\hline \multirow[t]{3}{*}{ Dukungan Informatif } & 26 & 24,3 & 63 & 58,9 & 18 & 16,8 & 107 & 100 \\
\hline & \multicolumn{3}{|c|}{ Belum baik } & \multicolumn{3}{|c|}{ Baik } & \multicolumn{2}{|c|}{ Total } \\
\hline & $\mathbf{n}$ & & $\%$ & $\mathbf{n}$ & & $\%$ & $\mathbf{n}$ & $\%$ \\
\hline Perikalu KADARZI & 85 & & 76,4 & 22 & & 20,6 & 107 & 100 \\
\hline Menimbang berat badan balita secara teratur & 12 & & 11,2 & 95 & & 88,8 & 107 & 100 \\
\hline Memberikan ASI Eksklusif & 35 & & 32,7 & 72 & & 67,3 & 107 & 100 \\
\hline Makan beraneka ragam & 79 & & 73,8 & 28 & & 26,2 & 107 & 100 \\
\hline Menggunakan garam beryodium & 1 & & 0,9 & 106 & & 99,1 & 107 & 100 \\
\hline Memberikan suplemen gizi sesuai anjuran (vit. A) & 4 & & 3,7 & 103 & & 96,3 & 107 & 100 \\
\hline
\end{tabular}

Tabel 3. Tabulasi silang hubungan dukungan keluarga dengan perilaku ibu dalam melaksanakan program keluarga sadar gizi (KADARZI) pada kasus balita dengan kurang gizi.

\begin{tabular}{|c|c|c|c|c|c|c|}
\hline \multirow{3}{*}{ Dukungan Keluarga } & \multicolumn{4}{|c|}{ Perilaku KADARZI } & \multirow{2}{*}{\multicolumn{2}{|c|}{ Total }} \\
\hline & \multicolumn{2}{|c|}{ Belum baik } & \multicolumn{2}{|c|}{ Baik } & & \\
\hline & $\mathbf{n}$ & $\%$ & $\mathbf{n}$ & $\%$ & $\mathbf{n}$ & $\%$ \\
\hline Kurang & 39 & 36,4 & 2 & 1,9 & 41 & 38,8 \\
\hline Cukup & 44 & 41,1 & 4 & 3,7 & 48 & 44,9 \\
\hline Baik & 2 & 1,9 & 16 & 15,0 & 18 & 16,8 \\
\hline Total & 85 & 79,4 & 22 & 20,6 & 107 & 100 \\
\hline
\end{tabular}

Suatu keluarga dikatakan berperilaku KADARZI apabila telah berperilaku gizi yang baik dengan dicirikan kelima indikator terpenuhi dengan baik. Berdasarkan tabel 2 dapat diketahuai bahwa sebagian besar belum berperilaku KADARZI dengan baik yaitu sebanyak $85(79,4 \%)$.

Hasil uji statistik Spearman Rho didapatkan $\mathrm{p}=0,000$ yang menunjukkan terdapat hubungan yang bermakna antara dukungan keluarga dengan perilaku ibu balita kurang gizi dalam melaksanakan KADARZI. Kekuatan korelasinya bernilai 0,562 yang menunjukkan kekuatan korelasi yang bernilai sedang dengan arah korelasi yang positif.

\section{PEMBAHASAN}

\section{Dukungan Emosional}

Mayoritas ibu mendapatkan dukungan emosional yang cukup dari keluarga. Dukungan emosional dapat mencakup empati, keadaan peduli dan perhatian terhadap orang lain yang bersangkutan (Prasetyo, 2018). Peranan anggota keluarga yang lain dalam perkembangan balita, secara tidak langsung adalah dengan memberikan dukungan emosional kepada ibu (Fitriani, 2017).

Dukungan emosional yang diberikan kepada responden dalam penelitian ini berupa rasa perhatian dan kepedulian yang dapat mempengaruhi perilaku ibu dalam melaksanaan KADARZI. Hal tersebut dapat diketahui dengan memberikan pernyataan terkait dengan perhatian dan rasa peduli yang diberikan keluarga kepada responden. Sebagian besar responden jarang menerima dukungan dari keluarganya untuk menyiapkan makanan beragam setiap hari, hal ini dapat disebabkan karena pendapatan keluarga setiap bulannya kurang dari upah minimun kota sehingga keluarga tidak menyarankan untuk setiap hari mengkonsumsi makanan beragam setiap hari.

\section{Dukungan Penghargaan}

Hasil penelitian menunjukkan sebagian besar ibu memperoleh dukungan penghargaan yang cukup. Menurut Friedman (2013) dukungan penghargaan keluarga adalah bentuk afektif keluarga dalam meningkatkan status kesehatan. Melalui dukungan penghargaan ini responden akan mendapatkan pengakuan atas kemampuannya sekecil dan sesederhana apapun. Pengakuan dapat berupa pujian sehingga responden akan lebih merasa dihargai, disayangi dan diandalkan (Saputri, 2016).

Dukungan penghargaan yang diberikan keluarga kepada responden dalam penelitian ini berupa rasa dihargai atas perilaku responden dalam melaksanakan KADARZI. Menurut analisa peneliti bahwa responden yang tidak melaksanakan KADARZI dengan baik disebabkan karena tidak meneriman dukungan penghargaan dari keluarga. Keluarga tidak memuji dengan baik saat responden melaksanakan KADARZI sehingga akan menurunkan motivasi responden dalam melaksanakan KADARZI. Dukungan penghargaan merupakan salah satu faktor yang dibutuhkan oleh ibu dalam melaksanakan KADARZI, berdasarkan penelitian Saputri (2016) bahwa dukungan antara dukungan penghargaan dengan pelaksanaan KADARZI. 


\section{Dukungan Instrumental}

Hasil penelitian menunjukkan sebagian besar ibu memperoleh dukungan instrumental yang cukup. Dukungan instrumental keluarga adalah dukungan yang diberikan oleh keluarga secara langsung yang meliputi bantuan material berupa finansial atau jasa (Sarafino 2011 dalam Sutini, 2018). Dukungan instrumental dalam penelitian ini berupa pemberian fasilitas dan pembiayaan untuk dapat melaksanaan KADARZI. Dukungan instrumental keluarga secara tidak langsung diberikan untuk memperlancar perilaku ibu untuk melaksanakan KADARZI, seperti mengantarkan ibu dan balita untuk menimbang ke posyandu dan membantu merawat saat balita dalam masa ASI ekslusif.

Dukungan keluarga yang kurang atau cukup dapat disebabkan karena sebagian besar perekonomian keluarga responden yang tergolong masih rendah sehingga keluarga belum mampu mendukung secara finansial untuk dapat menerapkan KADARZI terutama pada indikator makan makanan beragam setiap hari.

\section{Dukungan Informatif}

Mayoritas ibu mendapatkan dukungan informatif yang cukup dari keluarga. Dukungan informatif yang diberikan keluarga kepada responden merupakan salah satu bentuk fungsi perawatan kesehatan keluarga (Friedman, 2013). Tingkat pendidikan, usia, dan pekerjaan akan berpengaruh terhadap pengalaman dan paparan informasi yang diterima oleh keluarga. Tingkat pengetahuan keluarga yang baik akan sangat berhubungan dengan dukungan dalam keluarga (Firmansyah, 2017).

Bentuk dukungan informatif yang diberikan keluarga dalam penelitian ini adalah terkait dengan memberikan saran atau masukan, nasehat, serta ikut berdiskusi dalam pelaksanaan KADARZI. Menurut analisis penulis, dukungan informatif yang rendah disebabkan karena tingkat pendidikan responden yang tergolong rendah. Keluarga tidak memiliki pengetahuan yang cukup tentang KADARZI sehingga tidak dapat memberikan informasi atau ikut berdiskusi dengan responden tentang pentingnya KADARZI.

\section{Perilaku Ibu dalam Melaksanakan KADARZI: Menimbang Berat Badan Secara Teratur}

Hasil rekapitulasi data yang didapatkan 12 responden yang tidak membawa balitanya untuk ditimbang di posyandu secara teratur, 8 responden berpendidikan rendah yaitu pendidikan terakhir SD dan SMP. Orang tua dengan pendidikan yang baik akan mengerti bagaimana mengasuh anak dengan baik, menggunakan fasilitas pelayanan kesehatan dengan baik dan menjaga kebersihan lingkungan (Septikasari, 2018).

Hal ini sejalan dengan penelitian yang dilakukan Djamil (2017) faktor-faktor yang berhubungan dengan perilaku ibu balita menimbang anaknya ke posyandu antara lain adalah pengetahuan, sikap, dukungan keluarga, tokoh masyarakat dan dukungan kader.

Perilaku ibu yang tidak teratur membawa balitanya untuk ditimbang di posyandu dapat dipengaruhi oleh kurangnya pengetahuan akan pentingnya penimbangan balita secara rutin di posyandu, agar status gizi balita dapat terpantau dengan baik. Tidak ada anggota keluarga yang mengingatkan jadwal penimbangan di posyandu juga dapat mempengaruhi perilaku ibu dalam menimbang balita ke posyandu.

\section{Perilaku Ibu dalam Melaksanakan KADARZI: Memberikan ASI ekslusif}

Berdasarkan hasil penelitian, persentase ibu balita yang memberikan ASI ekslusif adalah $67,3 \%$ dan $32,7 \%$ tidak memberikan ASI eksklusif. Indikator memberikan ASI eksklusif ini dikatakan baik jika balita hanya diberikan ASI saja, tidak diberikan makanan dan minuman lain saat berusia 0-6 bulan.

Hasil penelitian Prastiwi (2018) faktor yang menyebabkan kegagalan ASI eksklusif adalah tingkat pendidikan ibu, peran suami, pengetahuan ibu, kondisi ASI, dan riwayat menyusui sebelumnya. Responden yang tidak memberikan ASI eksklusif sebagian besar berpendidikan terakhir SMP. Hal ini menunjukkan bahwa tingkat pendidikan akan mempengaruhi tingkat pengetahuan ibu mengenai pentingnya memberikan ASI eksklusif untuk anaknya. Sebagian besar ibu telah memberikan makanan lain seperti susu formula, pisang, tajin, dan madu saat anak masih berusia dibawah 6 bulan. Ibu yang mempunyai pendidikan tinggi mayoritas akan mau dan mampu untuk menerima informasi tentang pentingnya ASI eksklusif.

\section{Perilaku Ibu dalam Melaksanakan KADARZI: Makan makanan beraneka ragam}

Hasil penelitian menunjukkan bahwa hanya $26,2 \%$ responden yang berperilaku makan beraneka ragam dengan baik. Hal ini menunjukkan bahwa masih rendahnya konsumsi makanan yang beragam pada keluarga balita. Indikator makan makanan beraneka ragam adalah balita mengkonsumsi makanan pokok, lauk pauk, sayur dan buah setiap hari, namun indikator ini dikatakan baik jika balita mengkonsumsi lauk hewani dan buah setiap hari. Sebagian besar frekuensi balita untuk mengkonsumsi lauk hewani dan buah-buahan adalah 3-4 hari sekali saja per minggu, padahal menurut indikator penilaian KADARZI bahwa balita harus makan lauk hewani dan buah-buahan setiap hari.

Menurut Sulistyoningsih (2018) faktor yang mempengaruhi pola pemberian makan adalah tingkat pendidikan kan penghasilan. Mengkonsumsi makanan secara beraneka ragam merupakan perilaku yang sangat mempengaruhi keadaan gizi adalah pola makan. Hal ini disebabkan karena tingkat kesehatan individu dipengaruhi oleh kuantitas dan kualitas makanan dan minuman yang dikonsumsi. Tingkat konsumsi makanan akan dipengaruhi oleh penghasilan dan harga dari sebuah produk makanan. 
Hasil rekapitulasi data menunjukkan bahwa 78 responden yang belum memberikan balitanya makanan beragam memiliki pendapatan keluarga kurang dari UMR Kota Surabaya. Hal ini sesuai dengan penelitian yang dilakukan Septikasari (2018) faktor yang mempengaruhi orang tua dalam pemenuhan gizi anaknya menunjukkan bahwa keluarga dengan pendapatan dibawah UMR 3,2 kali lebih beresiko memberikan nutrisi yang tidak adekuat dibandingkan keluarga dengan pendapatan diatas UMR. Keluarga dengan perekonomian rendah atau menengah bawah tidak memberikan balitanya makanan yang beragam setiap harinya. Rendahnya pendapatan menyebabkan keluarga tidak mampu untuk membeli bahan makanan yang beraneka ragam terutama untuk membeli lauk hewani dan buah-buahan, sehingga balita tidak dapat mengkonsumsi makanan yang beragam setiap hari.

\section{Perilaku Ibu dalam Melaksanakan KADARZI:}

\section{Menggunakan Garam Beryodium}

Hasil penelitian menunjukkan bahwa 99,1\% responden telah menggunakan garam beryodium untuk setiap kali memasak. Garam yang digunakan mengandung yodium dibuktikan dengan terdapat keterangan "garam beryodium" pada kemasan garam. Indikator KADARZI menggunakan garam beryodium dinyatakan baik jika keluarga menggunakan garam beryodium untuk memasak setiap hari.

Kekurangan yodium pada usia dini akan berdampak pada terhambatnya pertumbuhan dan perkembangan serta mengakibatkan gangguan kecerdasan. WHO merekomendasikan untuk mengiodidasi garam untuk konsumsi sehari-hari untuk mencegah penyakit akibat kekurangan yodium (GAKY) (WHO, 2014).

Hampir seluruh responden dalam penelitian ini telah mengkonsumsi garam beryodium. Hal ini disebabkan karena garam yang beredar dimasyarakat saat ini telah mengandung yodium sehingga hampir semua rumah tangga telah menggunakan garam beryodium untuk memasak. Hanya terdapat 1 responden yang belum menggunakan garam beryodium, menurut hasil rekapitulasi data responden tersebut berpendidikan akhir SMP yang termasuk berpendidikan rendah. Hal ini sejalan penelitian yang dilakukan Sutinah (2017) yang mengungkapkan faktor yang berhubungan dengan penggunaan garam beryodium ditingkat rumah tangga adalah pengetahuan ibu tentang garam beryodium, sikap ibu tentang garam beryodium, dukungan keluarga/tenaga kesehatan, dan jarak tempuh pembelian garam beryodium.

\section{Perilaku Ibu dalam Melaksanakan KADARZI: Memberikan Suplemen Gizi Sesuai Anjuran} Hasil penelitian menunjukkan persentase pemberian kapsul vitamin A pada balita sebesar 96,3\%, hanya 4 balita yang tidak memperoleh kapsul vitamin $\mathrm{A}$. Suplemen vitamin A diberikan kepada bayi yang berumur 6-11 bulan, anak berumur 1-5 tahun, dan ibu nifas. Vitamin A berguna untuk meningkatkan kesehatan mata dan mencegah rabun senja, serta meningkatkan daya tahan tubuh untuk melawan penyakit. Manfaat suplemen vitamin A bagi bayi dan anak adalah agar bayi/anak lebih kebal dan jarang terkena penyakit, sedangkan bagi ibu nifas adalah untuk meningkatkan kandungan vitamin A dalam ASI dan agar kesehatan ibu cepat pulih setelah melahirkan (Departemen Kesehatan RI, 2012).

Menurut hasil penelitian (Nafijah, 2017) bahwa balita yang mendapatkan kapsul vitamin A sejak umur 6 bulan memiliki peluang sebesar 37\% untur terhindar dari resiko underweight daripada balita yang tidak mendapatkan kapsul vitamin A sejak umur 6 bulan. Penelitian Febrianti (2018) menjelaskan terdapat hubungan antara tingkat pengetahuan ibu tentang vitamin A dengan perilaku pemberian vitamin A pada balita.

Responden yang balita nya tidak mendapatkan vitamin A yaitu responden yang berpendidikan terakhir SMP dan SMA. Menurut hasil wawancara kepada ibu balita yang tidak mendapatkan kapsul vitamin A, pada saat jadwal pemberian vitamin A ibu balita tidak pergi ke posyandu karena kurangnya informasi mengenai jadwal pemberian vitamin A dan kurangnya pengetahuan tentang manfaat dari vitamin $\mathrm{A}$.

\section{Hubungan Dukungan Keluarga dengan Perilaku Ibu Balita Kurang Gizi dalam Melaksanakan KADARZI}

Penelitian ini menunjukkan bahwa terdapat hubungan yang bermakna antara dukungan keluarga dengan perilaku ibu balita kurang gizi dalam melaksanakan KADARZI. Kekuatan korelasinya menunjukkan kekuatan hubungan yang bernilai sedang dengan arah hubungan positif atau searah yang artinya jika dukungan keluarga yang dimiliki oleh responden baik maka perilaku KADARZI akan baik pula, begitupun sebaiknya jika dukungan keluarga rendah maka perilaku KADARZI akan rendah atau belum baik.

Berdasarkan hasil penelitian 22 responden yang telah melaksanakan KADARZI, 16 responden mendapatkan dukungan keluarga yang baik. Hasil penelitian ini sejalan dengan penelitian yang dilakukan Saputri (2016) mengungkapkan bahwa terdapat hubungan antara dukungan dari suami dengan pelaksanaan KADARZI. Namun berbeda dengan penelitian (Mustafyani, 2017)bahwa dukungan suami tidak berhubungan dengan perilaku KADARZI ibu balita gizi kurang $(p=0,861)$.

Berdasarkan hasil penelitian terdapat 2 responden yang memiliki dukungan keluarga baik namun belum melaksanakan KADARZI dengan baik. Menurut hasil tabulasi data didapatkan 2 responden tersebut merupakan ibu yang bekerja dan indikator KADARZI yang belum dilaksanakan adalah menimbang berat badan balita secara rutin. Hal ini sejalan dengan penelitian Rahmatika (2018) bahwa ada hubungan pekerjaan ibu dengan partisipasi menimbang balita di posyandu. Menurut asumsi peneliti ibu yang bekerja tidak mempunyai waktu luang untuk menimbangkan balitanya di posyandu, 
hal ini dikarenakan jadwal posyandu yang diadakan pada hari aktif dan pada jam kerja (jam 09.00 pagi). Berdasarkan wawancara peneliti dengan 2 responden tersebut mengatakan bahwa jika tidak ada yang membawa anaknya ke posyandu untuk menimbang saat ibu bekerja.

Menurut teori Lawrence Green, dukungan keluarga merupakan salah satu faktor pendorong yang dapat mempengaruhi perilaku kesehatan individu. sedangkan menurut teori Maslow, tingkah laku manusia dipengaruhi oleh kebutuhannya. Dukungan keluarga yang kurang akan membuat responden tidak memiliki movitasi untuk melaksanakan seluruh indikator KADARZI. Hal ini menunjukkan bahwa ibu membutukan dukungan dari keluarga untuk dapat melaksanakan KADARZI dengan baik, dukungan yang dibutuhkan berupa dukungan emosional, dukungan penghargaan, dukungan instrumental dan dukungan informatif. Dalam sebuah keluarga yang bertugas untuk mencari nafkah adalah suami, sehingga dengan mendapatkan ijin dari suami dan diberikan biaya untuk membeli kebutuhan yang berkaitan dengan pelaksanaan KADARZI akan mempermudah ibu dalam keberhasilan melaksanakan KADARZI.

Hasil analisis data 84 responden yang belum melaksanakan KADARZI merupakan keluarga yang berpenghasilan rendah, hal ini sejalan dengan penelitian Kardina (2015) yang menyatakan terdapat hubungan antara penghasilan keluarga dengan status KADARZI. Penghasilan keluarga merupakan salah satu faktor yang mempermudah penerapan KADARZI.

Keluarga memberikan perawatan kesehatan berupa salah satunya dengan memberikan dukungan informatif, sehingga dibutuhkan informasi antara satu sama lain dalam keluarga. Jika keluarga memberikan informasi dan ikut berdiskusi secara langsung dengan ibu tentang pentingnya melaksanakan KADARZI dan memberikan dukungan kepada ibu makan hal tersebut dapat membuat ibu terdorong untuk melaksanakan seluruh indikator KADARZI dengan baik. Semakin baik pengetahuan ini mengenai KADARZI akan semakin baik pula perilaku ibu dalam melaksanakan KADARZI, hal ini sejalan dengan penelitian Aulia (2019) yang menyatakan bahwa ada hubungan pengetahuan ibu tentang KADARZI dengan perilaku KADARZI.

Dukungan keluarga berupa selalu menyarankan dan mengingatkan ibu untuk melaksanakan KADARZI, selalu memuji apa yang dilakukan ibu terkait KADARZI, membantu merawat balita, mengantarkan ke posyandu, menyediakan biaya untuk membeli makanan beragam, dan selalu ikut berdiskusi dalam melaksanakan KADARZI merupakan bentuk dukungan yang dapat membuat ibu merasa dipedulikan dan didukungan untuk dapat melaksanakan KADARZI dengan baik sehingga dapat mempercepat pemulihan status gizi balita kurang gizi.

Menurut peneliti faktor pendorong untuk seseorang berperilaku sehat adalah adanya dukungan dari keluarga. Ibu akan termotivasi untuk melaksanakan KADARZI jika mendapatkan dukungan dari orang terdekat termasuk keluarga. Keluarga berperan sangat penting dalam tahapan perawatan kesehatan, dimulai dari tahapan peningkatan kesehatan, pencegahan, pengobatan, sampai dengan rehabilitasi. Keluarga berada dalam satu ikatan dan saling mempengaruhi antar anggota keluarga satu dengan yang lainnya sehingga keluarga dipandang sebagai satu kesatuan dari sejumlah anggota keluarga. Sehingga, terdapat hubungan yang kuat dalam keluarga dengan status kesehatan anggotanya (Effendi \& Makhfudli, 2009).

\section{KESIMPULAN}

Berdasarkan hasil penelitian didapatkan semakin baik dukungan keluarga maka akan semakin baik pula perilaku ibu balita kurang gizi dalam melaksanakan KADARZI. Sebagian besar dukungan keluarga yang dirasakan oleh ibu balita kurang gizi dalam melaksanakan KADARZI dalam kategori cukup. Dukungan keluarga yang paling banyak dirasakan adalah dukungan instrumental dan dukungan keluarga yang paling sedikit dirasakan adalah dukungan emosional. Sebagian besar ibu balita kurang gizi belum melaksanakan KADARZI dengan baik. Dari kelima indikator KADARZI, indikator makan makanan beragam merupakan indikator pencapaian yang paling rendah.

Bagi responden diharapkan lebih meningatkan kesadaran agar dapat menerapkan perilaku gizi yang baik serta lebih terbuka dalam menerima informasi dari petugas kesehatan mengenai KADARZI sebagai upaya dalam pemulihan gizi balitanya.

Peneliti selanjutnya diharapkan dapat memberikan intervensi terkait dengan pendidikan kesehatan mengenai pentingnya KADARZI bagi semua pihak, sehingga tingkat pelaksanaan KADARZI dapat semakin meningkat.

\section{DAFTAR PUSTAKA}

Dinas Kesehatan Surabaya. (2018). Profil Kesehatan Kota Surabaya 2017. Surabaya.

Djamil, A. (2017). Faktor-Faktor yang Berhubungan dengan Perilaku Ibu Balita Menimbang Anaknya ke Posyandu. Jurnal Kesehatan, 8(1), 127-134. https://doi.org/10.26630/jk.v8i1.409

Effendi, F., \& Makhfudli. (2009). Keperawatan Kesehatan Komunitas: Teori dan Praktik dalam Keperawatan. Jakarta: Salemba Medika.

Firmansyah, R. S., Lukman, M., \& Mambangsari, C. W. (2017). Faktor-Faktor yang Berhubungan dengan Dukungan Keluarga dalam Pencegahan Primer. Jurnal Keperawatan, 5(2), 197-213.

Fitriani, I. S., Oktobriariani, R. R., \& King, E. M. (2017). Stimulasi , Deteksi dan Intervensi Dini Orang Tua terhadap Pencegahan Penyimpangan Pertumbuhan dan Perkembangan Anak Balita. Indonesian Journal for Health Sciences, 1(1), 1-9.

Kardina, N. A. (2015). Hubungan Antara Karateristik Ibu, Keluarga, dan Pelayanan Kesehatan dengan 
Status Keluarga Sadar Gizi pada Keluarga Anak Balita (Studi di Wilayah Puskesmas Prajekan, Kabupaten Bondowoso) (Universitas Jember). https://doi.org/10.1242/jcs.150862

Kementrian Kesehatan RI. (2017). Profil Kesehatan Indonesia 2017. Jakarta.

Kementrian Kesehatan RI. (2018). Data dan Informasi Profil Kesehatan Indonesia. Jakarta.

Maria, H., Joko, W., \& Dewi, N. (2017). Hubungan Dukungan Keluarga dalam Pemenuhan Gizi Anak dengan Status Gizi Anak Usia Toddler. Nursing News: Jurnal Ilmiah Keperawatan, 2(1), 472-477.

Menteri Kesehatan RI. Peraturan Menteri Kesehatan Republik Indonesia Nomor 23 Tahun 2014 tentang Upaya Perbaikan Gizi. , (2014).

Mustafyani, A. D., \& Mahmudiono, T. (2017). Hubungan Pengetahuan, Sikap, Dukungan Suami, Kontrol Perilaku, dan Niat Ibu Dengan Perilaku KADARZI Ibu Balita Gizi Kurang. The Indonesian Journal of Public Health, 12(No. 2), 190-201. https://doi.org/10.20473/ijph.v12i1.2017.190201

Nafijah, M., Wardoyo, A. S., \& Mahmudiono, T. (2017). Hubungan Frekuensi Penimbangan, Penggunaan Garam Beryodium, dan Pemberian Vitamin A dengan Kejadian Underweight pada Balita di Provinsi Jawa Timur. Media Gizi Indonesia, 12(1), 40-46.

Nursalam. (2015). Metodologi Penelitian Ilmu Keperawatan (4 ed.). Jakarta: Salemba Medika.

Nurul Aulia, D. L., \& Dwi Anjani, A. (2019). Hubungan Pengetahuan dan Sikap Ibu Balita dengan Perilaku Keluarga Sadar Gizi (KADARZI). Journal for Quality in Women's Health, 2(No. 1), 36-42. https://doi.org/10.30994/jqwh.v2i1.25

Oktalina, O., Muniroh, L., \& Adiningsih, S. (2015). Hubungan Dukungan Suami dan Dukungan Keluarga dengan Pemberian ASI Eksklusif pada Ibu Anggota Kelompok Pendukung ASI (KP-ASI). Media Gizi Indonesia, 10(1), 64-70. https://doi.org/ 10.20473/mgi.v10i1.64-70

Prasetyo, A. Y. (2018). Analisis Pengaruh Konflik Keluarga, Pekerjaan, Hardiness, Self Efficacy Terhadap Stress Kerja Dengan Dukungan Sosial sebagai Variabel Moderasinya. Jurnal Psikologi.

Prastiwi, F. D. (2018). Analisis Faktor-Faktor Kegagalan ASI Eksklusif di Puskesmas Perak Timur Surabaya. Universitas Airlangga.

Rahmatika, S. D. (2018). Hubungan Pekerjaan Ibu dan Dukungan Keluarga dengan Partisipasi Penimbangan Balita ke Posyandu. Jurnal Kesehatan, 6(1), 9-17.

Saputri, I. M., Sulistiyana, \& Rohmawati, N. (2016). Peran dan Fungsi Kader, Dukungan Sosial Suami , dan Pengetahuan Tentang Budaya Keluarga pada Pelaksanaan Keluarga Sadar Gizi ( Roles and Functions of Cadre, Husband Social Support, and Knowledge of Family Culture on the Implementation of Nutrition Cons. Pustaka Kesehatan, 4(No. 1), 168-174. https://doi.org/ISSN 2355-178X

Sutinah. (2017). Faktor yang Berhubungan dengan
Penggunaan Garam Beriodium Tingkat Rumah Tangga. Jurnal of Health Education, 2(2), 179184. https://doi.org/10.15294/jhe.v2i2.17727

Wijayanti, S., \& Nindya, T. S. (2017). Hubungan Penerapan Perilaku Kadarzi (Keluarga Sadar Gizi) dengan Status Gizi Balita di Kabupaten Tulungagung Relationship of Kadarzi ( Family Conscious Nutrition ) Behavior Practice to Nutritional Status of Children Under Five Years in Tulungagung Distr. Amerta Nutrition, 379-388. https://doi.org/10.20473/amnt.v1.i4.2017.378388 